\title{
PENILAIAN KINERJA KARYAWAN DENGAN MENGGUNAKAN METODE FUZZY SIMPLE ADDITIVE WEIGHTED (FSAW) (Studi Kasus di Titi Sari Collection)
}

\author{
Hayatun Nufus ${ }^{1}$, Wudjud Soepeno Dihardjo ${ }^{2}$, Agus Solikin ${ }^{3}$ \\ Program Studi Pendidikan Matematika, FKIP UMSurabaya \\ hayatun56@yahoo.co.id
}

\begin{abstract}
ABSTRAK
Penilaian kinerja karyawan di Titi Sari Collection dilakukan dengan mengamati karyawan kemudian data diolah secara manual sehingga terdapat kesalahan-kesalahan dalam penginputan data karyawan dan penilaian prestasi kerja, ini semua dikarenakan penilaian Titi Sari Collection ini dilakukan secara subjektif. Tujuan penelitian ini adalah mengetahui hasil penilaian kinerja karyawan di Titi Sari Collection dengan menggunakan metode Fuzzy Simple Additive Weighted (FSAW).

Penelitian ini dilakukan di Titi Sari Collection, Dukun-Gresik dengan subjek karyawan Titi Sari Collection pada bidang jahit dan objek adalah kinerja suatu karyawan tersebut. Penelitian ini merupakan penelitian terapan dan studi kasus dengan menggunakan pendekatan deskriptif atau survey. Teknik pengumpulan data diperoleh dari studi kepustakaan wawancara, dan kuesioner. Kemudian data dianalisis dengan mereduksi, menyajikan dan menarik kesimpulan.

Dari hasil penelitian ini dapat disimpulkan bahwa Dengan adanya penilaian kinerja karyawan dengan menggunakan metode Fuzzy Simple Additive Weighted (FSAW) yang diterapkan di karyawan bidang jahit Titi Sari Collection, akan membantu pihak manajemen dalam menilai kinerja karyawan karena dengan metode FSAW tersebut merupakan salah satu alternatif yang lebih baik dari alternative lainnya dan dapat menggunakan lebih dari satu kriteria. Selain itu juga, penilaian dengan menggunakan metode Fuzzy Simple Additive Weighted (FSAW) mempunyai perbedaa yang signifikan, karena didasarkan pada nilai kriteria dan bobot yang sudah ditentukan.
\end{abstract}

Kata kunci : Kinerja, karyawan bidang jahit, Metode Fuzzy Simple Additive Weighted (FSAW)

\section{PENDAHULUAN}

Pada hakekatnya keberhasilan suatu instansi dalam mencapai tujuan-tujuan yang telah ditetapkan sangat tergantung pada kesiapan sumber daya manusia yang dimiliki, yang terlihat melalui pengetahuan terhadap standar pengerjaan yang dimiliki, kecakapan dalam menyelesaikan pekerjaan yang merupakan tanggung jawabnya, serta kualitas atas pekerjaan yang dilaksanakan. 
Untuk mengetahui potensi dari setiap pegawai pada instansi dilakukan penilaian terhadap kinerja pegawai dan memberikan pemahaman terkait pentingnya pemetaan potensi dan kualitas karyawan. Penilaian adalah suatu usaha yang dilakukan dalam pengambilan keputusan terhadap sesuatu dengan ukuran baik-buruk yang bersifat kualitatif. (Adhenarlin, 2010). Menurut menurut Wherter (dalam Harahap, 2012:15) penilaian kinerja berfungsi sebagai : (1) Keputusan untuk penempatan, yaitu dapat dilakukannya penempatan karyawan sesuai dengan keahliannya. (2) Pelatihan dan pengembangan, yaitu melalui penilaian akan diketahui kelemahan-kelemahan dari karyawan sehingga dapat dilakukan program pelatihan dan pengembangan yang lebih efektif. (3) Dapat mengidentifikasi adanya kekurangan dalam desain pekerjaan, yaitu kekurangan kinerja yang menunjukkan adanya kekurangan dalam perancangan jabatan. (4) Umpan balik pada pelaksanaan fungsi manajemen sumber daya manusia, yaitu dengan diketahuinya kinerja karyawan secara keseluruhan, ini akan menjadi informasi sejauh mana fungsi sumber daya manusia berjalan dengan baik atau tidak.

Fuzzy artinya kabur atau samar. Menurut (Kusumadewi dan Purnomo, 2010) metode fuzzy digunakan karena (1) Konsep logika fuzzy mudah dimengerti. (2) Logika fuzzy sangat fleksibel. (3) Logika fuzzy memiliki toleransi terhadap datadata yang tidak tepat. (4) Logika fuzzy mampu memodelkan fungsi-fungsi nonlinear yang sangat kompleks.

Terdapat beberapa metode fuzzy untuk menyelesaikan permasalahan penilaian prestasi karyawan, antara lain dengan menggunakan Multi Attribute Decision Making (MADM) dengan metode Simple Additive Weighting (SAW), Weighted Product (WP), ELECTRE, TOPSIS, Analytic Hierarchy Process (AHP).

Menurut Alireza, dkk (2012) dalam "Simple Additive Weighting Approach to Personnel Selection Problem" bahwa SAW mengabaikan fuzziness of executives selama proses pengambilan keputusan. Selain itu, beberapa kriteria dapat memiliki struktur kualitatif atau memiliki struktur yang tidak pasti dan tidak dapat diukur dengan tepat. Metode ini menentukan nilai bobot untuk setiap atribut, kemudian dilanjutkan dengan proses perangkingan yang akan menyeleksi alternatif terbaik dari sejumlah alternatif, dalam hal ini alternatif yang dimaksud adalah yang berhak menerima reward berdasarkan kriteria-kriteria yang ditentukan. Adapun langkah-langkah FSAW menurut (Maulana, 2012) adalah: (1) 
Menentukan kriteria-kriteria (C) yang akan dijadikan acuan dalam pengambilan keputusan. (2) Menentukan rating kecocokan setiap alternatif pada setiap kriteria. (3) Membuat matriks keputusan berdasarkan kriteria (C), kemudian melakukan normalisasi matriks berdasarkan persamaan yang disesuaikan dengan jenis atribut (atribut keuntungan (benefit) ataupun atribut biaya (cost)) sehingga diperoleh matriks ternomalisasi R. Adapun normalisasi matriks keputusan dengan atribut keuntungan (benefit) ditentukan dengan rumus $R_{i j}=\frac{x_{i j}}{\max _{i j}}$. Sedangkan normalisasi matriks keputusan dengan atribut biaya (cost) ditentukan dengan rumus $R_{i j}=$ $\frac{\operatorname{minx}_{i j}}{x_{i j}}$. (4) Hasil akhir diperoleh dari proses perankingan yaitu penjumlahan dari perkalian matriks ternomalisasi $\mathrm{R}$ dengan vektor bobot sehingga diperoleh nilai terbesar yang dipilih sebagai alternatif terbaik (A) sebagai solusi penyelesaian dengan menggunakan rumus $V_{i}=\sum_{j=1}^{n} W_{j} r_{i j}$.

Metode FSAW juga memiliki kelebihan, diantaranya : (1) Menentukan nilai bobot untuk setiap atribut, kemudian dilanjutkan dengan proses perangkingan yang akan menyeleksi alternatif terbaik dari sejumlah alternatif. (2) Penilaian akan lebih tepat karena didasarkan pada nilai kriteria dan bobot yang sudah ditentukan. Selain memiliki kelebihan, FSAW juga memiliki kekurangan, yaitu : (1) Perhitungan dilakukan dengan menggunakan bilangan crisp. (2) Adanya perbedaan perhitungan normalisasi matriks sesuai dengan nilai atribut (antara nilai benefit dan nilai cost).

Titi Sari Collection merupakan sebuah instansi yang bergerak dibidang produksi jilbab muslim. Instansi ini memiliki karyawan yang jumlahnya selalu meningkat, hal ini dikarenakan jumlah permintaan produksi yang semakin bertambah. Selain itu, instansi ini memiliki bidang-bidang pekerjaan yang banyak, diantarnya: bidang jahit, sulam, payet, neci, border computer, border corneli, penjaga toko, dan pengemasan produk. Kondisi saat ini, penilaian dilakukan dengan mengamati karyawan kemudian data diolah secara manual, dengan cara merekap nilai, kemudian dilakukan perhitungan dengan cara menjumlahkan nilai dari setiap kriteria, sehingga didapatkan nilai total dari setiap karyawan. Data yang diolah secara manual ini masih banyak terjadi kesalahan dalam penginputan data karyawan dan penilaian prestasi kerja, ini semua dikarenakan penilaian Titi Sari Collection ini dilakukan secara subjektif. 


\section{METODE PENELITIAN}

Jenis penelitian ini menggunakan penelitian terapan, dimaksudkan untuk menguji teori atau ilmu yang sudah ada untuk keperluan praktis yang bermanfaat secara langsung dalam kehidupan manusia. Selain itu, penelitian ini merupakan penelitian studi kasus dengan menerapkan teori dan mensimulasikan pada data di lapangan dari beberapa sumber, diantaranya dari buku-buku maupun internet.

Penelitian ini pada bulan April 2015 sampai tujuan penelitian tercapai. Subjek penelitian ini adalah karyawan bidang jahit Titi Sari Collection dengan menggunakan metode Fuzzy Simple Additive Weighted (FSAW).

Teknik pengumpulan data di atas dengan menggunakan studi kepustakaan, wawancara dan kuesioner. Studi kepustakaan yaitu dengan mempelajari literatur berkaitan dengan teori yang dibutuhkan untuk penilaian kinerja karyawan. Wawancara adalah teknik pengumpulan data yang dilakukan melalui tatap muka dan tanya jawab langsung antara pengumpul data maupun peneliti terhadap nara sumber atau sumber data. Wawancara ini digunakan untuk menguatkan data yang diperoleh dari kuesioner. (Fatihudin dan Holisin, 2011:26). Sedangkan kuesioner adalah sederetan daftar pertanyaan yang dibuat secara tertulis oleh peneliti untuk memperoleh data atau informasi yang berupa jawaban-jawaban yang diberikan oleh responden. Kuesioner ini merupakan data variabel nominal, maka skor yang diberikan hanya label yang memiliki skala peringkat. Adapun aturan pensokoring dalam kuesioner ini menggunakan aturan positif dengan skor 4-3-2-1. (Widoyoko, 2012:70).

Adapun teknik analisis data ini adalah mereduksi data, menyajikan data, dan penarikan simpulan.

\section{HASIL PENELITIAN DAN PEMBAHASAN}

Data yang digunakan adalah karyawan bidang jahit di Titi Sari Collection. Pada penelitian ini diambil 30 karyawan bidang jahit. Adapun langkah-langkah perhitungan kinerja karyawan dengan menggunakan metode metode Fuzzy Simple Additive Weighted (FSAW) adalah sebagai berikut: 
1. Mengolah kuesioner dengan menggunakan aturan positif dengan skor 4-3-2-1.

Tabel 1. Kriteria Penilaian Kinerja Karyawan Titi Sari Collection dengan Kuesioner

\begin{tabular}{|c|c|c|c|c|c|c|c|c|c|}
\hline \multirow{2}{*}{ No } & \multirow{2}{*}{ Nama } & \multicolumn{8}{|c|}{ Nilai Kriteria } \\
\hline & & C1 & $\mathrm{C2}$ & C3 & $\mathrm{C4}$ & C5 & C6 & C7 & C8 \\
\hline 1 & Dhirwah & $\begin{array}{l}\text { Sangat } \\
\text { Baik }\end{array}$ & Baik & Baik & Cukup & Baik & $\begin{array}{l}\text { Sangat } \\
\text { Baik }\end{array}$ & $\begin{array}{l}\text { Sangat } \\
\text { Baik }\end{array}$ & $\begin{array}{c}\text { Sangat } \\
\text { Baik }\end{array}$ \\
\hline 2 & Khus & Cukup & Cukup & Cukup & Cukup & Baik & Baik & $\begin{array}{c}\text { Sangat } \\
\text { Baik }\end{array}$ & $\begin{array}{c}\text { Sangat } \\
\text { Baik }\end{array}$ \\
\hline 3 & Iin & \begin{tabular}{|c|} 
Sangat \\
Baik \\
\end{tabular} & Cukup & Cukup & $\begin{array}{c}\text { Sangat } \\
\text { Baik }\end{array}$ & Baik & \begin{tabular}{|c|} 
Sangat \\
Baik
\end{tabular} & Baik & $\begin{array}{c}\text { Sangat } \\
\text { Baik }\end{array}$ \\
\hline 4 & Umrotul & Baik & Cukup & Cukup & $\begin{array}{c}\text { Sangat } \\
\text { Baik }\end{array}$ & Baik & \begin{tabular}{|c} 
Sangat \\
Baik
\end{tabular} & Baik & $\begin{array}{c}\text { Sangat } \\
\text { Baik }\end{array}$ \\
\hline 5 & Evi & Baik & Cukup & Cukup & $\begin{array}{c}\text { Sangat } \\
\text { Baik }\end{array}$ & Cukup & Baik & Baik & $\begin{array}{c}\text { Sangat } \\
\text { Baik }\end{array}$ \\
\hline 6 & Erna & $\begin{array}{l}\text { Sangat } \\
\text { Baik }\end{array}$ & Baik & Baik & $\begin{array}{l}\text { Sangat } \\
\text { Baik }\end{array}$ & Baik & Baik & Baik & $\begin{array}{c}\text { Sangat } \\
\text { Baik }\end{array}$ \\
\hline 7 & Usw & \begin{tabular}{|c|} 
Sangat \\
Baik \\
\end{tabular} & Cukup & Cukup & $\begin{array}{c}\text { Sangat } \\
\text { Baik }\end{array}$ & Baik & \begin{tabular}{|c} 
Sangat \\
Baik
\end{tabular} & Baik & $\begin{array}{c}\text { Sangat } \\
\text { Baik }\end{array}$ \\
\hline 8 & $\mathrm{~N}$ & \begin{tabular}{|c|} 
Sangat \\
Baik \\
\end{tabular} & \begin{tabular}{|c|} 
Sangat \\
Baik
\end{tabular} & Baik & Baik & $\begin{array}{c}\text { Sangat } \\
\text { Baik }\end{array}$ & Baik & $\begin{array}{l}\text { Sangat } \\
\text { Baik }\end{array}$ & $\begin{array}{c}\text { Sangat } \\
\text { Baik }\end{array}$ \\
\hline 9 & Nurul & \begin{tabular}{|c|} 
Sangat \\
Baik \\
\end{tabular} & Baik & Baik & $\begin{array}{c}\text { Sangat } \\
\text { Baik }\end{array}$ & $\begin{array}{c}\text { Sangat } \\
\text { Baik }\end{array}$ & Kurang & $\begin{array}{c}\text { Sangat } \\
\text { Baik }\end{array}$ & $\begin{array}{c}\text { Sangat } \\
\text { Baik }\end{array}$ \\
\hline 10 & Enda & \begin{tabular}{|c|} 
Sangat \\
Baik
\end{tabular} & \begin{tabular}{|c|} 
Sangat \\
Baik
\end{tabular} & \begin{tabular}{|c|} 
Sangat \\
Baik
\end{tabular} & Cukup & $\begin{array}{c}\text { Sangat } \\
\text { Baik }\end{array}$ & Baik & Baik & $\begin{array}{c}\text { Sangat } \\
\text { Baik }\end{array}$ \\
\hline 11 & Bak & Baik & $\mathrm{Cul}$ & Cukup & Baik & Baik & $\begin{array}{c}\text { Sangat } \\
\text { Baik }\end{array}$ & Baik & Baik \\
\hline 12 & Bik & Baik & Cukup & Cukup & Baik & Baik & $\begin{array}{c}\text { Sangat } \\
\text { Baik }\end{array}$ & Cukup & Baik \\
\hline 13 & Nikhlah & Baik & Baik & Cukup & Baik & Baik & Baik & Baik & Baik \\
\hline 14 & N & $\begin{array}{c}\text { Sangat } \\
\text { Baik }\end{array}$ & Kurang & $\begin{array}{c}\text { Sangat } \\
\text { Baik }\end{array}$ & Baik & $\begin{array}{c}\text { Sangat } \\
\text { Baik }\end{array}$ & Baik & $\begin{array}{c}\text { Sangat } \\
\text { Baik }\end{array}$ & $\begin{array}{c}\text { Sangat } \\
\text { Baik }\end{array}$ \\
\hline 15 & Zula & \begin{tabular}{|c|} 
Sangat \\
Baik \\
\end{tabular} & Baik & Baik & Cukup & Baik & Baik & Baik & $\begin{array}{c}\text { Sangat } \\
\text { Baik }\end{array}$ \\
\hline 16 & Lisa & \begin{tabular}{|c|} 
Sangat \\
Baik \\
\end{tabular} & Baik & \begin{tabular}{|c|} 
Sangat \\
Baik
\end{tabular} & Cukup & Baik & Baik & $\begin{array}{c}\text { Sangat } \\
\text { Baik }\end{array}$ & $\begin{array}{c}\text { Sangat } \\
\text { Baik }\end{array}$ \\
\hline 17 & Heti & Cukup & Baik & Baik & Baik & Baik & Baik & Baik & Cukup \\
\hline 18 & Nia & \begin{tabular}{|c|} 
Sangat \\
Baik \\
\end{tabular} & Cukup & Cukup & Baik & $\begin{array}{c}\text { Sangat } \\
\text { Baik }\end{array}$ & Baik & $\begin{array}{c}\text { Sangat } \\
\text { Baik }\end{array}$ & $\begin{array}{c}\text { Sangat } \\
\text { Baik }\end{array}$ \\
\hline 19 & Si’a & Baik & Cukup & Cukup & Baik & $\begin{array}{c}\text { Sangat } \\
\text { Baik }\end{array}$ & Baik & Baik & $\begin{array}{c}\text { Sangat } \\
\text { Baik }\end{array}$ \\
\hline 20 & Hali & Baik & Dain & Cukup & Baik & $\begin{array}{c}\text { Sangat } \\
\text { Baik }\end{array}$ & Baik & $\begin{array}{c}\text { Sangat } \\
\text { Baik }\end{array}$ & $\begin{array}{c}\text { Sangat } \\
\text { Baik }\end{array}$ \\
\hline 21 & Isna & $\begin{array}{c}\text { Sangat } \\
\text { Baik }\end{array}$ & Kurang & Kurang & $\begin{array}{c}\text { Sangat } \\
\text { Baik }\end{array}$ & Baik & $\begin{array}{c}\text { Sangat } \\
\text { Baik }\end{array}$ & Baik & $\begin{array}{c}\text { Sangat } \\
\text { Baik }\end{array}$ \\
\hline 22 & Sun & $\begin{array}{c}\text { Sangat } \\
\text { Baik }\end{array}$ & Cukup & Cukup & $\begin{array}{c}\text { Sangat } \\
\text { Baik }\end{array}$ & Baik & $\begin{array}{c}\text { Sangat } \\
\text { Baik }\end{array}$ & Baik & $\begin{array}{c}\text { Sangat } \\
\text { Baik }\end{array}$ \\
\hline 23 & Sirul & Baik & Cukup & Cukup & $\begin{array}{c}\text { Sangat } \\
\text { Baik }\end{array}$ & Baik & Kurang & Baik & $\begin{array}{c}\text { Sangat } \\
\text { Baik }\end{array}$ \\
\hline 24 & Yuyun & \begin{tabular}{|c|} 
Sangat \\
Baik
\end{tabular} & Baik & Baik & Baik & $\begin{array}{c}\text { Sangat } \\
\text { Baik }\end{array}$ & Baik & Baik & $\begin{array}{c}\text { Sangat } \\
\text { Baik }\end{array}$ \\
\hline 25 & Yati & Baik & Cukup & Baik & Baik & $\begin{array}{c}\text { Sangat } \\
\text { Baik }\end{array}$ & Kurang & Cukup & $\begin{array}{c}\text { Sangat } \\
\text { Baik }\end{array}$ \\
\hline
\end{tabular}


Hayatun Nufus' ${ }^{1}$, Wudjud Soepeno Dihardjo' ${ }^{2}$ Agus Solikin ${ }^{3}$

\begin{tabular}{|c|l|c|c|c|c|c|c|c|c|}
\hline No & Nama & \multicolumn{7}{|c|}{ Nilai Kriteria } \\
\cline { 3 - 9 } & C1 & C2 & C3 & C4 & C5 & C6 & C7 & C8 \\
\hline 27 & Zula M & Baik & Cukup & Baik & Baik & $\begin{array}{c}\text { Sangat } \\
\text { Baik }\end{array}$ & Baik & $\begin{array}{c}\text { Sangat } \\
\text { Baik }\end{array}$ & $\begin{array}{c}\text { Sangat } \\
\text { Baik }\end{array}$ \\
\hline 28 & Masrifah & Baik & $\begin{array}{c}\text { Sangat } \\
\text { Baik }\end{array}$ & Cukup & Baik & $\begin{array}{c}\text { Sangat } \\
\text { Baik }\end{array}$ & $\begin{array}{c}\text { Sangat } \\
\text { Baik }\end{array}$ & $\begin{array}{c}\text { Sangat } \\
\text { Baik }\end{array}$ & $\begin{array}{c}\text { Sangat } \\
\text { Baik }\end{array}$ \\
\hline 29 & Urifah & Cukup & Baik & Baik & Baik & $\begin{array}{c}\text { Sangat } \\
\text { Baik }\end{array}$ & $\begin{array}{c}\text { Sangat } \\
\text { Baik }\end{array}$ & Cukup & $\begin{array}{c}\text { Sangat } \\
\text { Baik }\end{array}$ \\
\hline 30 & Siti & Baik & Kurang & Cukup & Baik & Cukup & $\begin{array}{c}\text { Sangat } \\
\text { Baik }\end{array}$ & Cukup & $\begin{array}{c}\text { Sangat } \\
\text { Baik }\end{array}$ \\
\hline
\end{tabular}

2. Pada penelitian ini alternatif karyawan Titi Sari Collection (Bidang Jahit) yang dinilai ditandai dengan $\mathrm{A}_{1}$ sampai dengan $\mathrm{A}_{40}$, dengan uraian sebagai berikut:
$\mathrm{A}_{1}=$ Dhirwah
$\mathrm{A}_{11}=\mathrm{Bakha}$
$\mathrm{A}_{21}=$ Isna
$\mathrm{A}_{2}=$ Khusnul
$\mathrm{A}_{12}=$ Bikha
$\mathrm{A}_{22}=$ Sumiyati
$\mathrm{A}_{3}=$ Iin
$\mathrm{A}_{13}=$ Nikhlah
$\mathrm{A}_{23}=$ Sirul
$\mathrm{A}_{4}=$ Umrotul
$\mathrm{A}_{14}=$ Nunuk
$\mathrm{A}_{24}=$ Yuyun
$\mathrm{A}_{5}=\mathrm{Evi}$
$\mathrm{A}_{15}=\mathrm{Zula}$
$\mathrm{A}_{25}=$ Yati
$\mathrm{A}_{6}=$ Erna
$\mathrm{A}_{16}=$ Lisa
$\mathrm{A}_{26}=$ Darsih
$\mathrm{A}_{7}=$ Uswatun
$\mathrm{A}_{17}=$ Heti
$\mathrm{A}_{27}=$ Zula $\mathrm{M}$
$A_{8}=$ Nur Jannah
$\mathrm{A}_{18}=\mathrm{Nia}$
$\mathrm{A}_{28}=$ Masrifah
$\mathrm{A}_{9}=$ Nurul
$\mathrm{A}_{19}=\mathrm{Si}{ }^{\prime} \mathrm{a}$
$\mathrm{A}_{29}=$ Urifah
$\mathrm{A}_{10}=$ Endang
$\mathrm{A}_{20}=$ Halimah
$\mathrm{A}_{30}=$ Siti

3. Kriteria penilaian kinerja karyawan di Titi Sari Collection (Bidang Jahit) ditandai dengan $\mathrm{C}_{1}$ sampai dengan $\mathrm{C}_{8}$, dengan perincian sebagai berikut:
$\mathrm{C}_{1}=$ Kualitas dan Kuantitas Kerja
$\mathrm{C}_{5}=$ Disiplin Kerja
$\mathrm{C}_{2}=$ Kejujuran
$\mathrm{C}_{6}=$ Komunikasi
$\mathrm{C}_{3}=$ Kerjasama
$\mathrm{C}_{7}=$ Tanggung Jawab
$\mathrm{C}_{4}=$ Semangat Kerja
$\mathrm{C}_{8}=$ Kerapian

4. Sebelum menentukan rating kecocokan, maka ditentukan kriteria benefit dan kriteria cost. Adapun kriteria-kriterianya adalah:
Kriteria benefit adalah
Kriteria cost adalah
$\mathrm{C}_{1}$ : Kualitas dan Kuantitas Kerja
C3 : Kerjasama
$\mathrm{C}_{2}$ : Kejujuran
C4 : Semangat Kerja
$\mathrm{C}_{8}$ : Kerapian
C5 : Disiplin Kerja
C6 : Komunikasi
C7 : Tanggung Jawab 
5. Semua kriteria terbagi atas 5 (lima) bilangan fuzzy, yaitu Sangat Kurang, Kurang, Cukup, Baik, Sangat Baik. Bilangan bilangan fuzzy tersebut dapat dikonversikan ke bilangan crisp.

Sangat Kurang $=0$;

Cukup $=0.5$

Kurang $=0.25$;

Baik $=0.75$;

Sangat Baik $=1$

6. Melakukan konversi bilangan fuzzy ke bilangan crips atau membuat rating kecocokan setiap alternatif penyelesaian pada setiap kriteria penilaian kinerja karyawan Titi Sari Collection (Bidang Jahit).

Tabel 2. Hasil Konversi Bilangan Fuzzy Kebilangan Crips Dari Setiap Alternatif Pada Setiap Kriteria

\begin{tabular}{|c|l|c|c|c|c|c|c|c|c|}
\hline \multirow{2}{*}{ No } & \multicolumn{1}{|c|}{ Nama } & \multicolumn{9}{|c|}{ Nilai Kriteria } \\
\cline { 3 - 9 } & & $\mathbf{C 1}$ & $\mathbf{C 2}$ & $\mathbf{C 3}$ & $\mathbf{C 4}$ & $\mathbf{C 5}$ & $\mathbf{C 6}$ & $\mathbf{C 7}$ & $\mathbf{C 8}$ \\
\hline 1 & Dhirwah & 1 & 0.75 & 0.75 & 0.50 & 0.75 & 1 & 1 & 1 \\
\hline 2 & Khusnul & 0.50 & 0.50 & 0.50 & 0.50 & 0.75 & 0.75 & 1 & 1 \\
\hline 3 & Iin & 1 & 0.50 & 0.50 & 1 & 0.75 & 1 & 0.75 & 1 \\
\hline 4 & Umrotul & 0.75 & 0.50 & 0.50 & 1 & 0.75 & 1 & 0.75 & 1 \\
\hline 5 & Evi & 0.75 & 0.50 & 0.50 & 1 & 0.50 & 0.75 & 0.75 & 1 \\
\hline 6 & Erna & 1 & 0.75 & 0.75 & 1 & 0.75 & 0.75 & 0.75 & 1 \\
\hline 7 & Uswatun & 1 & 0.50 & 0.50 & 1 & 0.75 & 1 & 0.75 & 1 \\
\hline 8 & Nur Jannah & 1 & 1 & 0.75 & 0.75 & 1 & 0.75 & 1 & 1 \\
\hline 9 & Nurul & 1 & 0.75 & 0.75 & 1 & 1 & 0.25 & 1 & 1 \\
\hline 10 & Endang & 1 & 1 & 1 & 0.50 & 1 & 0.75 & 0.75 & 1 \\
\hline 11 & Bakha & 0.75 & 0.50 & 0.50 & 0.75 & 0.75 & 1 & 0.75 & 0.75 \\
\hline 12 & Bikha & 0.75 & 0.50 & 0.50 & 0.75 & 0.75 & 1 & 0.50 & 0.75 \\
\hline 13 & Nikhlah & 0.75 & 0.75 & 0.50 & 0.75 & 0.75 & 0.75 & 0.75 & 0.75 \\
\hline 14 & Nunuk & 1 & 0.25 & 1 & 0.75 & 1 & 0.75 & 1 & 1 \\
\hline 15 & Zula & 1 & 0.75 & 0.75 & 0.50 & 0.75 & 0.75 & 0.75 & 1 \\
\hline 16 & Lisa & 1 & 0.75 & 1 & 0.50 & 0.75 & 0.75 & 1 & 1 \\
\hline 17 & Heti & 0.50 & 0.75 & 0.75 & 0.75 & 0.75 & 0.75 & 0.75 & 0.50 \\
\hline 18 & Nia & 1 & 0.50 & 0.50 & 0.75 & 1 & 0.75 & 1 & 1 \\
\hline 19 & Si'a & 0.75 & 0.50 & 0.50 & 0.75 & 1 & 0.75 & 0.75 & 1 \\
\hline 20 & Halimah & 0.75 & 0.75 & 0.50 & 0.75 & 1 & 0.75 & 1 & 1 \\
\hline 21 & Isna & 1 & 0.25 & 0.25 & 1 & 0.75 & 1 & 0.75 & 1 \\
\hline 22 & Sumiyati & 1 & 0.50 & 0.50 & 1 & 0.75 & 1 & 0.75 & 1 \\
\hline 23 & Sirul & 0.75 & 0.50 & 0.50 & 1 & 0.75 & 0.25 & 0.75 & 1 \\
\hline 24 & Yuyun & 1 & 0.75 & 0.75 & 0.75 & 1 & 0.75 & 0.75 & 1 \\
\hline 25 & Yati & 0.75 & 0.50 & 0.75 & 0.75 & 1 & 0.25 & 0.50 & 1 \\
\hline 26 & Darsih & 1 & 0.75 & 0.50 & 0.75 & 0.75 & 0.75 & 1 & 1 \\
\hline 27 & Zula M & 0.75 & 0.50 & 0.75 & 0.75 & 1 & 0.75 & 1 & 1 \\
\hline 28 & Masrifah & 0.75 & 1 & 0.50 & 0.75 & 1 & 1 & 1 & 1 \\
\hline 29 & Urifah & 0.50 & 0.75 & 0.75 & 0.75 & 1 & 1 & 0.50 & 1 \\
\hline 30 & Siti & 0.75 & 0.25 & 0.50 & 0.75 & 0.50 & 1 & 0.50 & 1 \\
\hline
\end{tabular}

7. Selanjutnya, tentukan terlebih dahulu pembobotan dari setiap kriteria (w). Pembobotan kriteria penilaian kinerja karyawan Titi Sari Collection ini lebih mengutamakan tingkat kejujuran, kualiatas dan kuantitas kerja, kerapian, 
disiplin kerja, komunikasi, kerjasama, semangat kerja, dan tanggung jawab. Pembototan setiap kriteria ini harus berjumlah 1.

Tabel 3 Hasil Pembobotan Setiap Kriteria

\begin{tabular}{|c|c|c|}
\hline No & Kriteria & Bobot \\
\hline 1 & C1 & 0.2 \\
\hline 2 & C2 & 0.25 \\
\hline 3 & C3 & 0.07 \\
\hline 4 & C4 & 0.06 \\
\hline 5 & C5 & 0.08 \\
\hline 6 & C6 & 0.08 \\
\hline 7 & C7 & 0.06 \\
\hline 8 & C $~$ & 0.2 \\
\hline
\end{tabular}

8. Membuat matriks keputusan berdasarkan kriteria, kemudian melakukan normalisasi matriks berdasarkan persamaan yang disesuaikan dengan jenis atribut (atribut keuntungan ataupun atribut biaya), sehingga diperoleh matriks normalisasi R.

Tabel 4. Tabel Matriks Keputusan Setiap Kriteria

\begin{tabular}{|c|c|c|c|c|c|c|c|}
\hline 1 & 0.75 & 0.75 & 0.50 & 0.75 & 1 & 1 & 1 \\
\hline 0.50 & 0.50 & 0.50 & 0.50 & 0.75 & 0.75 & 1 & 1 \\
\hline 1 & 0.50 & 0.50 & 1 & 0.75 & 1 & 0.75 & 1 \\
\hline 0.75 & 0.50 & 0.50 & 1 & 0.75 & 1 & 0.75 & 1 \\
\hline 0.75 & 0.50 & 0.50 & 1 & 0.50 & 0.75 & 0.75 & 1 \\
\hline 1 & 0.75 & 0.75 & 1 & 0.75 & 0.75 & 0.75 & 1 \\
\hline 1 & 0.50 & 0.50 & 1 & 0.75 & 1 & 0.75 & 1 \\
\hline 1 & 1 & 0.75 & 0.75 & 1 & 0.75 & 1 & 1 \\
\hline 1 & 0.75 & 0.75 & 1 & 1 & 0.25 & 1 & 1 \\
\hline 1 & 1 & 1 & 0.50 & 1 & 0.75 & 0.75 & 1 \\
\hline 0.75 & 0.50 & 0.50 & 0.75 & 0.75 & 1 & 0.75 & 0.75 \\
\hline 0.75 & 0.50 & 0.50 & 0.75 & 0.75 & 1 & 0.50 & 0.75 \\
\hline 0.75 & 0.75 & 0.50 & 0.75 & 0.75 & 0.75 & 0.75 & 0.75 \\
\hline 1 & 0.25 & 1 & 0.75 & 1 & 0.75 & 1 & 1 \\
\hline 1 & 0.75 & 0.75 & 0.50 & 0.75 & 0.75 & 0.75 & 1 \\
\hline 1 & 0.75 & 1 & 0.50 & 0.75 & 0.75 & 1 & 1 \\
\hline 0.50 & 0.75 & 0.75 & 0.75 & 0.75 & 0.75 & 0.75 & 0.50 \\
\hline 1 & 0.50 & 0.50 & 0.75 & 1 & 0.75 & 1 & 1 \\
\hline 0.75 & 0.50 & 0.50 & 0.75 & 1 & 0.75 & 0.75 & 1 \\
\hline 0.75 & 0.75 & 0.50 & 0.75 & 1 & 0.75 & 1 & 1 \\
\hline 1 & 0.25 & 0.25 & 1 & 0.75 & 1 & 0.75 & 1 \\
\hline 1 & 0.50 & 0.50 & 1 & 0.75 & 1 & 0.75 & 1 \\
\hline 0.75 & 0.50 & 0.50 & 1 & 0.75 & 0.25 & 0.75 & 1 \\
\hline 1 & 0.75 & 0.75 & 0.75 & 1 & 0.75 & 0.75 & 1 \\
\hline 0.75 & 0.50 & 0.75 & 0.75 & 1 & 0.25 & 0.50 & 1 \\
\hline 1 & 0.75 & 0.50 & 0.75 & 0.75 & 0.75 & 1 & 1 \\
\hline 0.75 & 0.50 & 0.75 & 0.75 & 1 & 0.75 & 1 & 1 \\
\hline 0.75 & 1 & 0.50 & 0.75 & 1 & 1 & 1 & 1 \\
\hline 0.50 & 0.75 & 0.75 & 0.75 & 1 & 1 & 0.50 & 1 \\
\hline 0.75 & 0.25 & 0.50 & 0.75 & 0.50 & 1 & 0.50 & 1 \\
\hline
\end{tabular}


Berdasarkan tabel rating kecocokan, dapat dibentuk matriks keputusan dibentuk sebagai berikut:

$$
\left[\begin{array}{ccc}
1 & \cdots & 1 \\
\vdots & \ddots & \vdots \\
0.75 & \cdots & 1
\end{array}\right]
$$

Tabel 5. Normalisasi Matriks

\begin{tabular}{|c|l|c|c|c|c|c|c|c|c|}
\hline \multirow{2}{*}{ No } & \multicolumn{1}{|c|}{ Nama } & \multicolumn{9}{|c|}{ Nilai Kriteria } \\
\cline { 2 - 10 } & & $\mathbf{C 1}$ & $\mathbf{C 2}$ & $\mathbf{C 3}$ & $\mathbf{C 4}$ & $\mathbf{C 5}$ & $\mathbf{C 6}$ & $\mathbf{C 7}$ & C8 \\
\hline 1 & Dhirwah & 1 & 0.75 & 0.33 & 1 & 0.67 & 0.25 & 0.50 & 1 \\
\hline 2 & Khusnul & 0.50 & 0.50 & 0.50 & 1 & 0.67 & 0.33 & 0.50 & 1 \\
\hline 3 & Iin & 1 & 0.50 & 0.50 & 0.50 & 0.67 & 0.25 & 0.67 & 1 \\
\hline 4 & Umrotul & 0.75 & 0.50 & 0.50 & 0.50 & 0.67 & 0.25 & 0.67 & 1 \\
\hline 5 & Evi & 0.75 & 0.50 & 0.50 & 0.50 & 1 & 0.33 & 0.67 & 1 \\
\hline 6 & Erna & 1 & 0.75 & 0.33 & 0.50 & 0.67 & 0.33 & 0.67 & 1 \\
\hline 7 & Uswatun & 1 & 0.50 & 0.50 & 0.50 & 0.67 & 0.25 & 0.67 & 1 \\
\hline 8 & Nur Jannah & 1 & 1 & 0.33 & 0.67 & 0.50 & 0.33 & 0.50 & 1 \\
\hline 9 & Nurul & 1 & 0.75 & 0.33 & 0.50 & 0.50 & 1 & 0.50 & 1 \\
\hline 10 & Endang & 1 & 1 & 0.25 & 1 & 0.50 & 0.33 & 0.67 & 1 \\
\hline 11 & Bakha & 0.75 & 0.50 & 0.50 & 0.67 & 0.67 & 0.25 & 0.67 & 0.75 \\
\hline 12 & Bikha & 0.75 & 0.50 & 0.50 & 0.67 & 0.67 & 0.25 & 1 & 0.75 \\
\hline 13 & Nikhlah & 0.75 & 0.75 & 0.50 & 0.67 & 0.67 & 0.33 & 0.67 & 0.75 \\
\hline 14 & Nunuk & 1 & 0.25 & 0.25 & 0.67 & 0.50 & 0.33 & 0.50 & 1 \\
\hline 15 & Zula & 1 & 0.75 & 0.33 & 1 & 0.67 & 0.33 & 0.67 & 1 \\
\hline 16 & Lisa & 1 & 0.75 & 0.25 & 1 & 0.67 & 0.33 & 0.50 & 1 \\
\hline 17 & Heti & 0.50 & 0.75 & 0.33 & 0.67 & 0.67 & 0.33 & 0.67 & 0.50 \\
\hline 18 & Nia & 1 & 0.50 & 0.50 & 0.67 & 0.50 & 0.33 & 0.50 & 1 \\
\hline 19 & Si’a & 0.75 & 0.50 & 0.50 & 0.67 & 0.50 & 0.33 & 0.67 & 1 \\
\hline 20 & Halimah & 0.75 & 0.75 & 0.50 & 0.67 & 0.50 & 0.33 & 0.50 & 1 \\
\hline 21 & Isna & 1 & 0.25 & 1 & 0.50 & 0.67 & 0.25 & 0.67 & 1 \\
\hline 22 & Sumiyati & 1 & 0.50 & 0.50 & 0.50 & 0.67 & 0.25 & 0.67 & 1 \\
\hline 23 & Sirul & 0.75 & 0.50 & 0.50 & 0.50 & 0.67 & 1 & 0.67 & 1 \\
\hline 24 & Yuyun & 1 & 0.75 & 0.33 & 0.67 & 0.50 & 0.33 & 0.67 & 1 \\
\hline 25 & Yati & 0.75 & 0.50 & 0.33 & 0.67 & 0.50 & 1 & 1 & 1 \\
\hline 26 & Darsih & 1 & 0.75 & 0.50 & 0.67 & 0.67 & 0.33 & 0.50 & 1 \\
\hline 27 & Zula M & 0.75 & 0.50 & 0.33 & 0.67 & 0.50 & 0.33 & 0.50 & 1 \\
\hline 28 & Masrifah & 0.75 & 1 & 0.50 & 0.67 & 0.50 & 0.25 & 0.50 & 1 \\
\hline 29 & Urifah & 0.50 & 0.75 & 0.33 & 0.67 & 0.50 & 0.25 & 1 & 1 \\
\hline 30 & Siti & 0.75 & 0.25 & 0.50 & 0.67 & 1 & 0.25 & 1 & 1 \\
\hline
\end{tabular}

9. Selanjutnya, mengalikan setiap kolom pada tabel tersebut dengan bobot kriteria yang sudah ditentukan di atas dengan rumus $V_{i}=\sum_{j=1}^{n} W_{j} r_{i j}$.

10. Dari hasil perkalian kolom pada tabel dengan bobot kriteria di atas, maka langkah selanjutnya aadalah merangkingkan atau menurutkan karyawan yang mempunyai nilai tertinggi ke karyawan yang mempunyai nilai terendah. Sehingga diperoleh: 
Hayatun Nufus', Wudjud Soepeno Dihardjo², Agus Solikin ${ }^{3}$

Tabel 5 Hasil Akhir Metode Fuzzy Simple Additive Weighted (FSAW)

\begin{tabular}{|c|c|c|c|}
\hline No & Nama & Total Nilai & Perangkingan \\
\hline 1 & Dhirwah & 0,77 & 6 \\
\hline 2 & Khusnul & 0,63 & 26 \\
\hline 3 & Iin & 0,70 & 14 \\
\hline 4 & Umrotul & 0,65 & 23 \\
\hline 5 & Evi & 0,69 & 18 \\
\hline 6 & Erna & 0,76 & 9 \\
\hline 7 & Uswatun & 0,70 & 15 \\
\hline 8 & Nur Jannah & 0,81 & 2 \\
\hline 9 & Nurul & 0,79 & 3 \\
\hline 10 & Endang & 0,83 & 1 \\
\hline 11 & Bakha & 0,61 & 29 \\
\hline 12 & Bikha & 0,63 & 27 \\
\hline 13 & Nikhlah & 0,68 & 19 \\
\hline 14 & Nunuk & 0,62 & 28 \\
\hline 15 & Zula & 0,79 & 4 \\
\hline 16 & Lisa & 0,78 & 5 \\
\hline 17 & Heti & 0,57 & 30 \\
\hline 18 & Nia & 0,70 & 16 \\
\hline 19 & Si'a & 0,66 & 22 \\
\hline 20 & Halimah & 0,71 & 12 \\
\hline 21 & Isna & 0,68 & 20 \\
\hline 22 & Sumiyati & 0,70 & 17 \\
\hline 23 & Sirul & 0,71 & 13 \\
\hline 24 & Yuyun & 0,76 & 10 \\
\hline 25 & Yati & 0,72 & 11 \\
\hline 26 & Darsih & 0,77 & 7 \\
\hline 27 & Zula M & 0,64 & 25 \\
\hline 28 & Masrifah & 0,77 & 8 \\
\hline 29 & Urifah & 0,67 & 21 \\
\hline 30 & Siti & 0,65 & 24 \\
\hline
\end{tabular}

Berdasarkan dari data di atas, jika dibandingkan antara perhitungan penilaian kinerja karyawan dengan membagikan kuesioner agar tidak mengandung unsur subjektif, yaitu dihitung dengan metode FSAW dan dengan manual yang sudah diterapkan oleh Titi Sari Collection sebelumnya tanpa membagikan kuesioner, maka diperoleh tabel sebagai berikut:

Tabel 6 Perbandingan Perhitungan Manual dan FSAW

\begin{tabular}{|c|l|c|c|c|c|}
\hline No & Nama & $\begin{array}{c}\text { Total Nilai } \\
\text { FSAW }\end{array}$ & Perangkingan & $\begin{array}{c}\text { Total Nilai } \\
\text { Manual }\end{array}$ & Perangkingan \\
\hline 1 & Dhirwah & 0,77 & 6 & 64 & 6 \\
\hline 2 & Khusnul & 0,63 & 26 & 62 & 18 \\
\hline 3 & Iin & 0,70 & 14 & 66 & 2 \\
\hline 4 & Umrotul & 0,65 & 23 & 60 & 30 \\
\hline 5 & Evi & 0,69 & 18 & 63 & 13 \\
\hline 6 & Erna & 0,76 & 9 & 64 & 7 \\
\hline 7 & Uswatun & 0,70 & 15 & 64 & 8 \\
\hline 8 & Nur Jannah & 0,81 & 2 & 67 & 1 \\
\hline
\end{tabular}




\begin{tabular}{|c|l|c|c|c|c|}
\hline No & \multicolumn{1}{|c|}{ Nama } & $\begin{array}{c}\text { Total Nilai } \\
\text { FSAW }\end{array}$ & Perangkingan & $\begin{array}{c}\text { Total Nilai } \\
\text { Manual }\end{array}$ & Perangkingan \\
\hline 9 & Nurul & 0,79 & 3 & 63 & 14 \\
\hline 10 & Endang & 0,83 & 1 & 62 & 19 \\
\hline 11 & Bakha & 0,61 & 29 & 61 & 24 \\
\hline 12 & Bikha & 0,63 & 27 & 64 & 9 \\
\hline 13 & Nikhlah & 0,68 & 19 & 64 & 10 \\
\hline 14 & Nunuk & 0,62 & 28 & 61 & 25 \\
\hline 15 & Zula & 0,79 & 4 & 65 & 4 \\
\hline 16 & Lisa & 0,78 & 5 & 61 & 26 \\
\hline 17 & Heti & 0,57 & 30 & 66 & 3 \\
\hline 18 & Nia & 0,70 & 16 & 63 & 15 \\
\hline 19 & Si'a & 0,66 & 22 & 63 & 16 \\
\hline 20 & Halimah & 0,71 & 12 & 62 & 20 \\
\hline 21 & Isna & 0,68 & 20 & 61 & 27 \\
\hline 22 & Sumiyati & 0,70 & 17 & 62 & 21 \\
\hline 23 & Sirul & 0,71 & 13 & 62 & 22 \\
\hline 24 & Yuyun & 0,76 & 10 & 61 & 28 \\
\hline 25 & Yati & 0,72 & 11 & 61 & 29 \\
\hline 26 & Darsih & 0,77 & 7 & 62 & 23 \\
\hline 27 & Zula M & 0,64 & 25 & 64 & 11 \\
\hline 28 & Masrifah & 0,77 & 8 & 64 & 12 \\
\hline 29 & Urifah & 0,67 & 21 & 63 & 17 \\
\hline 30 & Siti & 0,65 & 24 & 65 & 5 \\
\hline
\end{tabular}

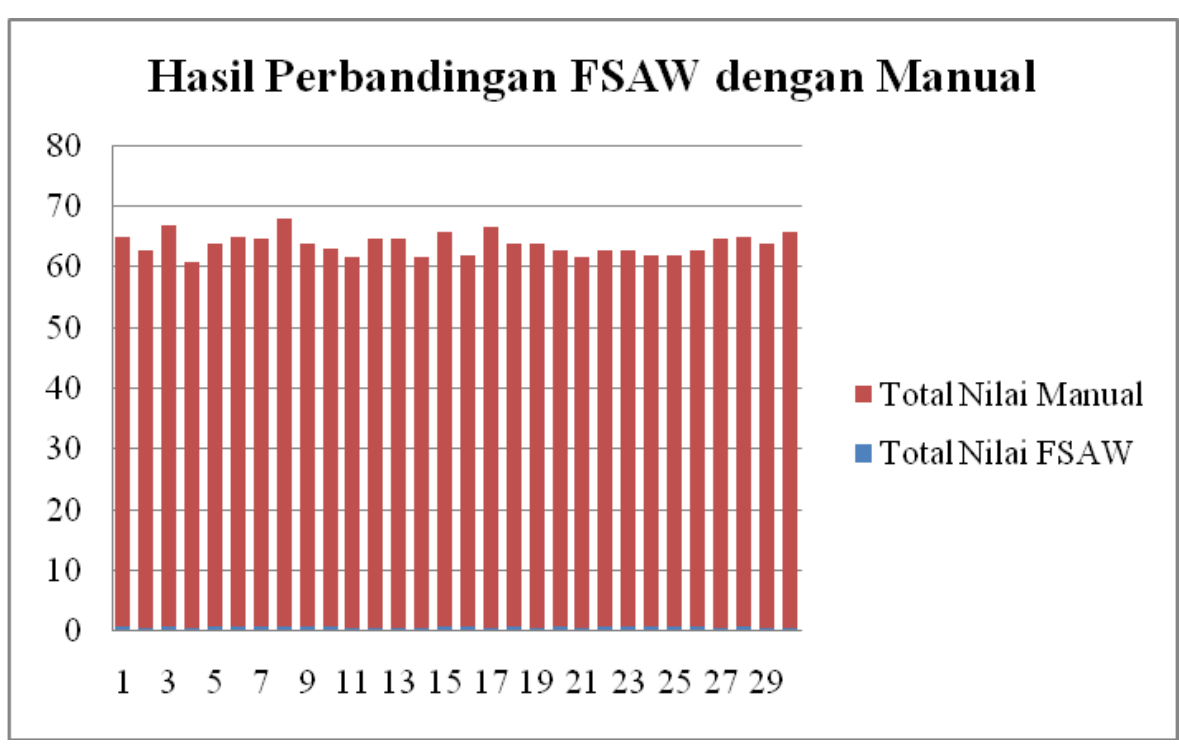

Gambar 1. Grafik Perbandingan Perhitungan Manual dan FSAW

Berdasarkan tabel dan diagram di atas, maka hasil perhitungan dengan membagikan kuesioner dan dihitung menggunakan metode Fuzzy Simple Additive Weighted (FSAW) lebih tepat dan objektif dibandingkan dengan cara manual tanpa membagikan kuesioner, hal tersebut dinilai subjektif karena penilaian dilakukan tanpa memperhatikan indikator-indikator setiap krieria yang di buat 
oleh Titi Sari Collection. Selain itu juga, metode Fuzzy Simple Additive Weighted (FSAW) ini dapat mengurutkan atau merangkingkan karyawan yang memiliki nilai terbaik. Penilaian dengan menggunakan metode Fuzzy Simple Additive Weighted (FSAW) memiliki perbedaan yang signifikan karena didasarkan pada nilai kriteria dan bobot proferensi yang sudah ditentukan.

\section{SIMPULAN}

Berdasarkan rumusan masalah dan pembahasan, sehingga dapat ditarik kesimpulan : Dengan adanya penilaian kinerja karyawan dengan menggunakan metode Fuzzy Simple Additive Weighted (FSAW) yang diterapkan di karyawan bidang jahit Titi Sari Collection, akan membantu pihak manajemen dalam menilai kinerja karyawan karena dengan metode FSAW tersebut merupakan salah satu alternatif yang lebih baik dari alternatif lainnya dan dapat menggunakan lebih dari satu kriteria. Selain itu juga, penilaian dengan menggunakan metode Fuzzy Simple Additive Weighted (FSAW) mempunyai perbedaan yang signifikan dibanding penilaian kinerja secara manual di Titi Sari Collection. Hal ini dikarenakan karena didasarkan pada nilai kriteria dan bobot yang sudah ditentukan.

\section{DAFTAR PUSTAKA}

Adhenarlin. 2010. http://adhenarlin.wordpress.com/2010/03/19/pengertianpengukuran-penilaian-dan-evaluasi. (Diakses pada tanggal 14 Januari 2015).

Alireza, dkk. 2012. Simple Additive Weighting approach to Personnel Selection problem. Jurnal Ilmiah ICTech. X (1): 1-2.

Fatihudin, didin dan Iis Holisin. 2011. Cara Praktis Memahami Penulisan Karya Ilmiah, Artikel Ilmiah \& Hasil Penelitian Kripsi, Tesis, dan Disertasi. Yogyakarta: Unit Penerbit dan Percetakan Sekolah Tinggi Ilmu Manajemen YKPN.

Harahap, Mara Halim. 2012. Sistem Pendukung Keputusan Penilaian Kinerja Karyawan Dengan Menggunakan Metode Simple Additive Weighted (SAW) Studi Kasus di PT. Bank Tabungan Negara (Persero) tbk. Cabang Karawang. Bandung: Universitas Komputer Indonesia (UNIKOM).

Kusumadewi, Sri dan Purnomo, H., 2010. Aplikasi Logika Fuzzy untuk System Pendukung Keputusan. Yogyakarta: Andi Offset.

Maulana, Muhammad Rifqi. 2012. http://ictech-muchrifqim-16-1-penilaianw.pdf. (Diakses pada tanggal 20 Januari 2015).

Widoyoko, Eko Putro. 2012. Teknik Penyusunan Instrumen Penelitian. Yogyakarta: Pustaka Pelajar. 